\title{
Development of STSE-based learning devices to improve the character of environmental care

\section{Zuhair Abdullah}

Institut Agama Islam Negeri (IAIN) Pekalongan, Indonesia zuhair.abdullah@iainpekalongan.ac.id

\begin{tabular}{l}
\hline ARTICLE INFO \\
\hline Article history \\
Received January 15, 2020 \\
Revised April 20, 2020 \\
Accepted June 6, 2020 \\
\hline Keyword: \\
Development \\
Learning device \\
Environmental Care Character
\end{tabular}

\begin{abstract}
The character of environmental care is a serious problem in Indonesia, the low character of environmental care has an impact on environmental damage. One of the efforts to improve the character of environmental care for the community is through education, namely through the development of learning devices that can improve the character of environmental care. This study aims: 1) to produce a proper STSE-based device, 2) to produce a STSEbased device that is effective in enhancing the character of environmental care. This research is a development study using the Borg and Gall model. The developed device contains syllabus, lesson plans, handouts, and student's worksheets. The product developed was tested on a limited trial to 12 grade $X$ student's and wider trials on 37 students using a pretest posttest control group design. The instruments used to assess the product are syllabus validation sheets, lesson plan validation sheets, handout validation sheets, and student's worksheets validation sheets. The product was validated by 6 people, including two expert lecturers, two biology teachers, and two peers. The results showed: 1) the products produced were feasible in terms of content, graphics, and linguistics as evidenced by the average score of 4.2 in the very good category. 2) the resulting product is effective to improve the character of environmental care as evidenced by obtaining a score of 0.2 in the low category in the control class and 0.45 in the moderate category in the experimental class.
\end{abstract}

This is an open access article under the CC-BY-SA license.

\section{Introduction}

Text. One of the problems in Indonesia is the problem of the character of the people who are still low, especially the character of caring for the environment. We can see this through the phenomena around us, such as the presence of rubbish that fills the river flow, disposal of industrial waste without proper procedures, illegal logging, slaughter of wildlife, construction of buildings without regard to environmental impacts, fishing using poisons and bombs, vandalism and student brawls to damage public facilities, and various other negative actions that only aim to meet human greed in meeting their needs without considering environmental aspects. As a concrete example, the results of research conducted 
by Uar, Murti, \& Hadisusanto (2016), concluded that most of the coral reefs at the study site in Maluku Regency were in a heavily damaged condition. In addition, community perceptions about the importance of coral reef conservation are also still low, as indicated by the activities of coral reef exploitation to meet shortterm economic needs. Another example, the security forces found a large booty of 1 - 2m diameter wood that had been cut down. Giant timber was looted by illegal loggers destroying natural forests in Tesso Nilo National Park (Tanjung, 2020). These things indicate the low character of caring for the environment of our society, where people who have good character care about the environment will have attitudes and actions that always try to prevent damage to the surrounding natural environment, and develop efforts to repair natural damage that has been happen (Kemendiknas, 2010).

The low character of environmental care cannot be separated from the role of education. Therefore, the world of education through a curriculum that is appropriate to its field to discuss the environment, in this case is a Biology course, has a great responsibility to overcome the problem of the low character of the community's environmental care. This is because seeing Indonesia Law No. 20 of 2003 concerning the education system in article 3, explains that the education system basically functions to develop the ability and build the character and civilization of a dignified nation in order to educate the nation's life (Putri, 2012). Ratna Megawangi (cited as in, Purwanti, 2017) revealed that character education is an effort to educate children to be able to make wise decisions and practice them in their daily lives so that they can make a positive contribution to their environment.

According to Salirawati (2012), character education can be integrated in learning in each subject. According to Kosim (2011), The process of developing cultural values and national character must be carried out through each subject, in every curricular and extracurricular activities, and through school culture. Thus, in carrying out character education in schools, all components (stakeholders) must be involved, including the components of education itself, namely the contents of the curriculum, the learning process and assessment, the quality of relationships, the handling or management of subjects, school management, implementation of activities or cocurricular activities, infrastructure facilities empowerment, financing, and the work ethic of all citizens and the school environment. The learning approach used in the learning process is closely related to certain abilities that students are expected to have. Sanjaya (2008) states the approach as a starting point or point of view of the teacher towards the learning process. The selection of a good learning approach must adjust to the teaching material and consider certain abilities that student's want to achieve in order to achieve good learning outcomes and certain expected competencies. The STSE approach directs learning to raise real environmental issues into learning, so that students can understand environmental problems scientifically. Emphasis on knowledge about environmental damage and its negative impacts can certainly touch student's sense of environmental concern, so hopefully they can learn alternative solutions that are useful for solving these problems in society. Therefore, the STSE approach is very important to be realized in the biology learning devices on environmental change material. Learning devices are devices used in the learning process (Trianto, 2010). Learning devices can be in the form of syllabus, lesson plans, handouts, modules, student worksheets, questions, etc. that function to represent the learning approach used. The learning device has an important function because it is a reference in the implementation of the learning process. Sanjaya (2015) states that through careful and accurate planning, able to predict the success achieved, thus the possibility of failure can be anticipated. In addition, learning will take place in a focused and organized manner, as well as more effective use of time (Yuliani \& Saragih, 2015).

Uno (2011) states the effectiveness of learning can be described in four aspects, namely there are four important aspects to describe the effectiveness of learning, namely the accuracy of mastery of the behavior learned, the speed of performance, the level of learning transfer and the level of retention of what is learned. Through learning devices arranged based on a particular approach or model, certain abilities or behaviors that 
are expected to emerge can be accommodated. For example, biology learning devices containing character education with the guided inquiry setting developed by Jaya, Sadia, and Arnyana (2014) proven effective can improve positive character and student learning outcomes.

Akker, Bannan, Kelly, Nieveen, and Plomp (2007) states that learning devices developed can be said to be of quality if they meet three criteria, namely validity, practicality, and effectiveness. Learning devices are said to be valid if they meet certain criteria. According to Akker, Bannan, Kelly, Nieveen, and Plomp (2007) characteristics of the product that are said to be valid if it reflects the soul of knowledge (state of the art knowledge). This is what is said with content validation. Furthermore, the components of these products must be consistent with each other (construct validity). According to Nieveen (1999), the device is said to be practical if the device is easy and can be implemented, and is said to be effective if the learning objectives can be achieved through the use of developed learning devices.

Based on the results of interviews and observations with two Biology teachers at MA Wahid Hasyim Yogyakarta, information is obtained that biology teachers have not developed their learning devices optimally. Some of the problems found include: the absence of learning devices that accommodate the character of students caring about the environment, between one part of the device and other parts of the learning device are out of sync, the material presented in the device is not contextual to the lives of students, and also teachers sometimes have difficulty determining approaches learning that will be chosen to be poured in the learning devices in accordance with the abilities or skills expected, and they usually only use learning devices developed by others both from publishers and downloading from the internet.

Definition of Science Technology Society or "Science-Technology-Society" according to the National Science Teachers Associations (NSTA) is the study of science and technology in the context of human experience (Yager, Choi, Yager, \& Akcay, 2009). The addition of the element of Environment (E) in its context so that the development of science and technology can have a positive impact on the environment. Through the STSE approach that is applied to the material changes in the environment of students, it is directed to raise the issue of real environmental problems into the learning process, namely regarding the process, impact and prevention of environmental pollution. Therefore, by knowing the impact and handling it comprehensively, it can be assumed that this approach will be able to improve the environmental care character of students. Akcay and Yager (2010) states that learning this Community Science Technology includes eleven basic features that are important, namely (a) learners identify problems from the surrounding environment and impacts on their environment; (b) use of local resources (human and material) to find information that can be used in solving problems; (c) the active involvement of students in finding information that can be applied to solve problems in real life; (d) additional study time outside the classroom, in the classroom or at school; (e) focus on the impact of science and technology on each student; (f) the view that science content is not something that exists just like that for students; (g) pressure on process skills all the time just because they demonstrate special abilities through scientific practicum; (h) an emphasis on career awareness especially in careers related to science and technology; (i) opportunities for students to show their role in society so they try to solve problems; (j) identification is the way in which science and technology have the potential to have a great influence on the future; (k) some autonomy in the learning process as an individual problem has been identified and used to compile teaching. Implementation of science teaching in the Community Science Technology Learning Approach according to Poedjiadi (2010) divided into five stages: 1.) Introduction: Initiation/invitation/ apperception/exploration of students; 2.) Formation/Development of concepts (Appointment of issues or problems); 3.) Application of concepts in life: Problem solving or analysis of issues; 4.) Consolidation of Concepts; 5.) Rating.

Learning devices developed based on the STSE approach can increase environmental awareness. This is because learning that is connected with the environment will shape social attitudes and care for the environment Nurani, Ridlo, 
and Susilowati (2014). In addition, several studies have been conducted such as those conducted by Heni, Binadja, and Sulistyorini (2015) with the aim of developing a thematic learning device with a SETS vision with the character of caring for the environment which is proven effective in achieving student activity and student understanding. Other studies conducted by Vijayabanu and Amarnath (2013) concluded that knowledge and attitudes about the environment have a positive influence on environmental behavior. Other research was also conducted by Rosario (2008) which concluded that STSE learning applied to environmental science subjects with activities sourced from the local environment proved to be effective in increasing environmental attitudes. The learning devices developed in this study include syllabus, lesson plans, teaching materials (handouts), and student's worksheet in biology with environmental change material.

\section{Method}

This research is a development study using the Borg \& Gall development model. In this research, what is done is to develop learning devices using the STML approach to improve the student's environmental awareness character.

The development steps in this study that were adapted from the Borg \& Gall adaptation development design can be seen in Figure 1.

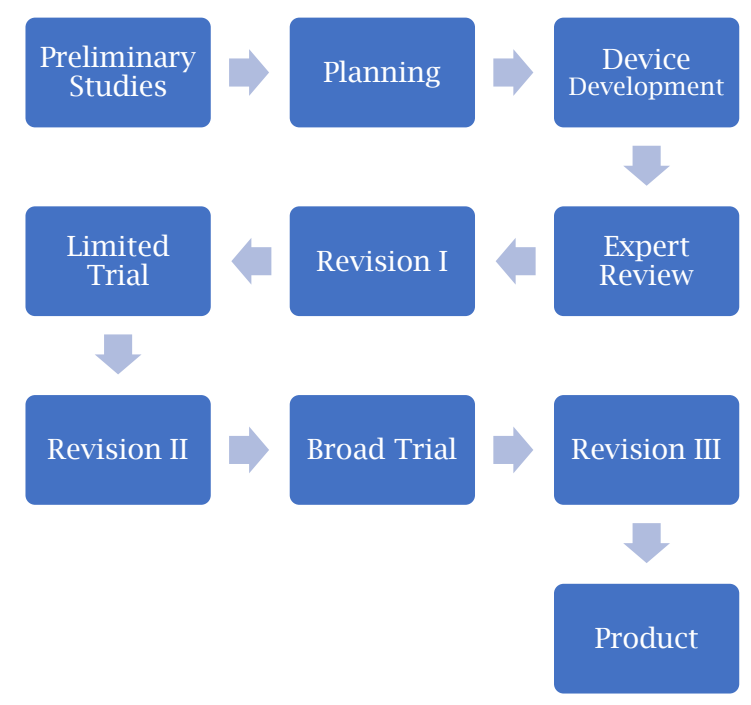

Figure 1.Design development of Gall, Gall, \& Borg (2003)
The instrument validators in this study consisted of six people including, two expert lecturers, two biology teachers, and two colleagues. The assessment instruments used in this study are, 1) the validation sheet of the learning kit; 2) observation sheets of the implementation of learning, 3) questionnaire responses of students to the product and learning process; 4) environmental character questionnaires.

The syllabus product assessment indicators include the suitability of indicators with basic competencies, the coverage of aspects of environmental care character in the indicators, the suitability of learning experiences with indicators, the adequacy of time allocation, the suitability of assessment points with indicators, the suitability of sources and material devices with indicators. Lesson plan product assessment indicators include the formulation of learning objectives, material selection, learning scenarios / activities, and assessment of learning outcomes. Handout product assessment indicators include material coverage, material accuracy, up-to-date, content values embedded in students, content based on science, technology, community, and environment models, conformity with student development level, communicative, dialogical and interactivity, appropriateness, coherence and to the flow of thought lines, conformity with Indonesian language rules, use of terms and symbols. Students worksheet product assessment indicators include the suitability of the material with the curriculum, the clarity of the formulation of learning objectives, the preparation of activities supporting the character of caring for the environment, linking activities to real life, the appropriateness of loading the subject matter and its details with the syntax of the STSE model, the appropriateness of the lesson sequence with the level of student ability, clarity of instructions for students on the topic covered, general direction, and the time available to work on it. Indicators to assess the instrument for observing the learning sheet include the suitability of the activities with the indicators of the implementation of the lesson plan components, the suitability of the activities so that they are not ambiguous, the suitability of the activities with measurement instructions, levels, type of 
school, and grade level, the use of grammar in activities, the use of words/generally accepted terms, and communicative. Indicators for assessing student's questionnaire responses to the product include the appropriateness of the statement with the student's response instrument to the apparatus and the learning process of the appropriateness of the statement so that it is not ambiguous, the appropriateness of the statement with measurement instructions, level, type of school and grade level, the use of grammar in the statement, the use words/terms that are generally accepted, and communicative. Indicators for evaluating the environmental care questionnaire include the appropriateness of the statement with the environmental care character indicator, the appropriateness of the statement so that it is not ambiguous, the appropriateness of the statement with measurement instructions, level, type of school and grade level, the use of grammar in the statement, the use of words/terms generally accepted, and communicative.

Rating scores given by the validator are then converted using a 5 scale according to Azwar (1999) presented in Table 1.

Table 1. Convert scores to five scale values

\begin{tabular}{lll}
\hline Value & \multicolumn{1}{c}{ Interval Score } & \multicolumn{1}{c}{ Category } \\
\hline $\mathrm{A}$ & $\mathrm{M}+1.5 \mathrm{~S}<\mathrm{X}$ & Very good \\
$\mathrm{B}$ & $\mathrm{M}+0.5 \mathrm{~S}<\mathrm{X} \leq \mathrm{M}+1.5 \mathrm{~S}$ & Good \\
$\mathrm{C}$ & $\mathrm{M}-0.5 \mathrm{~S}<\mathrm{X} \leq \mathrm{M}+0.5 \mathrm{~S}$ & Enough \\
$\mathrm{D}$ & $\mathrm{M}-1.5 \mathrm{~S}<\mathrm{X} \leq \mathrm{M}-0.5 \mathrm{~S}$ & Less \\
$\mathrm{E}$ & $\mathrm{X} \leq \mathrm{M}-1.5 \mathrm{~S}$ & Very less \\
\hline Information: & \\
$\mathrm{M} \quad:$ Mean \\
$\mathrm{M}$ & $: 1 / 2$ (ideal maximum score + ideal minimum \\
& score) \\
$\mathrm{S}$ & $:$ Standard deviation \\
$\mathrm{S}$ & $: 1 / 6$ (ideal maximum score - ideal minimum \\
& score) \\
$\mathrm{X}$ & $:$ : Actual score
\end{tabular}

The feasibility value of the product specified in this study is at least $C$ enough categories. Thus, the results of the assessment of media experts and material experts if they give the final result $C$ or enough, then the product of development is feasible to be used as a learning medium.

Limited trials were conducted on twelve students of class XA MA Wahid Hasyim Yogyakarta. At this stage students are given a questionnaire response sheet to assess their acceptance of the product and the learning process. This trial aims to obtain product readability information and about the course of the learning process by students.

Extensive testing was applied to 2 classes, namely XB class as a control class and $\mathrm{XC}$ as an experimental class. This stage aims to obtain data about the environmental care characteristics of students before and after following the learning process in the control and experiment class to determine the effectiveness of the product that has been developed. The learning process in the control class uses a conventional approach, while the experimental class uses the STSE approach with the product being developed including syllabus, lesson plans, handouts, and student's worksheet.

Field trials using quasi-experimental methods using Pretest Posttest Control Group Design. The trial design can be seen in Table 2.

Table 2. Pretest posttest control group design research design

\begin{tabular}{llll}
\hline \multicolumn{1}{c}{ Group } & $\begin{array}{l}\text { Pre } \\
\text { test }\end{array}$ & Treatment & $\begin{array}{c}\text { Post } \\
\text { test }\end{array}$ \\
\hline $\begin{array}{l}\text { Control class } \\
\text { Experimental }\end{array}$ & $\mathrm{T} 1$ & $\mathrm{Xa}$ & $\mathrm{T} 2$ \\
Class & $\mathrm{Tb}$ & $\mathrm{T} 2$ \\
\hline
\end{tabular}

Information:

(Sugiyono, 2014)

Xa: Learning using conventional devices

$\mathrm{Xb}$ : Learning using STSE learning devices

T1: The initial score of the character cares for the environment

T2: The final score for the character cares about the environment

Descriptive analysis of student's environmental care characteristics improvement was carried out using normalized gain data. Normalized gain calculation can be searched using formula 1 .

Information:

$$
\text { gain }=\frac{\mathrm{T} 2-T 1}{\mathrm{Is}-\mathrm{T} 1}
$$

T1: Pretest score

T2: Posttest score

Is: Maximum pretest or posttest score

(Hake, 1999)

Normalized gain of each student is then calculated on average. The average gain value of each student is categorized according to Hake (1999, see in Table 3).

In this study, it was determined that the learning device was concluded to be effective if the gain of the experimental class score was greater than the control class. 
Table 3. Categorization of student gain score

\begin{tabular}{ll}
\hline \multicolumn{1}{c}{ Interval } & \multicolumn{1}{c}{ Category } \\
\hline $\mathbf{0 . 7} \leq$ (g) & High \\
$\mathbf{0 . 3} \leq \mathbf{( g )}<\mathbf{0 . 7}$ & Medium \\
$\mathbf{( g )}<\mathbf{0 . 3}$ & Low \\
\hline
\end{tabular}

\section{Results and Discussion}

The results of research and development at the preliminary study stage, based on the results of interviews with teachers in the survey activities, the researchers obtained a number of information, namely: a.) The student's lack of concern for the environment, this can be seen from the condition of the class and school less clean and neat. b.) There is no learning device that accommodates student's environmental care characters. c.) The results of mastery of environmental change material for MA Wahid Hasyim Yogyakarta students are not optimal, this can be seen from the low minimal completeness criteria achievement. Based on the results of the field study, the researcher came to the conclusion that efforts to develop biology learning devices especially those that accommodate student's environmental care characteristics need to be done.

The planning phase is to do a task analysis, which is a collection of procedures to determine the contents of the lesson units. Task analysis is carried out by detailing the task content of the subject in the form of an outline. This analysis includes content structure analysis, concept analysis, and analysis of learning objectives.

Based on the 2013 curriculum the material for environmental change is analyzed and obtained as follows: a.) Basic Competence (Core Competency 3): 3.10 Analyzing data on environmental changes and the impact of these changes on life. b.) Basic Competence (Core Competency 4): 4.10 Solve environmental problems by designing waste recycling products and environmental preservation efforts. (basic competencies on core competencies-4)

The selected subject matter is Environmental Change, Study Material: Environmental Change, Environmental Balance, Environmental Pollution, Impact of Environmental Pollution, Intensification, Agriculture and Its Impact on the Environment, Integrated Environmental Management, Waste Management, and
Environmental Ethics. Concept analysis is done by identifying the main concepts in core competencies and basic competencies of environmental change material to be taught, systematically compiling, and detailing relevant concepts.

The formulation of learning objectives is based on concept analysis and task analysis, so that it is more operational. In the analysis of the task, the 2013 curriculum analysis has been elaborated which includes Core Competencies 3 and Core Competencies 4 as the basis for developing learning objectives. The following are the formulation of learning objectives that can be identified: a.) Through discussion of environmental issues students can explain the notion of environmental change appropriately. b.) Through discussion of environmental issues students can identify environmental changes caused by natural and human factors precisely. c.) Through discussion of environmental issues students can explain the notion of environmental balance appropriately. d.) through discussion of environmental issues learners can explain the notion of environmental pollution appropriately. e.) Through discussion of environmental issues students can explain the factors causing environmental pollution well. f.) through discussion of environmental issues learners can identify examples of pollutants properly. g.) through discussion of environmental issues learners can identify the impact of environmental pollution appropriately. h.) Through discussion of environmental issues students can identify the impact of intensification of agriculture on the environment appropriately. i.) through discussion of environmental issues learners can explain integrated environmental management properly. j.) Through the practice of recycling students can make recycled products properly as an effort to preserve the environment.

The preparation of the product draft is carried out on the lesson set in class $\mathrm{X}$ semester 2, adjusting to the background of the problem then choosing the material "Environmental Change: Environmental Pollution". Learning devices designed to be developed, namely syllabus, lesson plans, handouts, student's worksheet and assessment devices (environmental care character questionnaire sheets, lesson plan implementation sheets, questionnaire sheets, student responses). Plans for 
developing the entire planning device on the theoretical basis that has been compiled. The instrument used to measure the feasibility of the device developed was the validation sheet, while the effectiveness was used using a questionnaire.

The results of the assessment provided by the validator on aspects of content, graphics, and readability of the syllabus, lesson plan, handout, students worksheet, environmental care character questionnaire, student response questionnaire, and lesson plan observation sheet with a mean score of 4.2 get an A and have a very high category both so that it can be concluded that the initial product of the validated learning device is feasible or valid because the above categories are sufficient, so that it is feasible to be tested with the revision done beforehand. The results of the assessment are presented in Table 4.

Table 4. Average of validator ratings

\begin{tabular}{|c|c|c|c|c|c|c|}
\hline No. & Rated Device & $\begin{array}{l}\text { Expert } \\
\text { Lecturer }\end{array}$ & Teacher & $\begin{array}{c}\text { Peer } \\
\text { Reviewer }\end{array}$ & Average & Category \\
\hline 1. & Syllabus & 4.3 & 3.9 & 4.2 & 4.1 & Very Good \\
\hline 2. & Lesson Plan & 4.4 & 3.9 & 4.1 & 4.1 & Very Good \\
\hline 3. & Handout & 4.1 & 4.3 & 4.2 & 4.2 & Very Good \\
\hline 4. & Students worksheet & 4.5 & 4.2 & 4.1 & 4.3 & Very Good \\
\hline 6. & $\begin{array}{l}\text { Environmental care } \\
\text { character Questionnaire }\end{array}$ & 4.4 & 4.5 & 4.2 & 4.4 & Very Good \\
\hline 7. & $\begin{array}{l}\text { Questionnaire responses of } \\
\text { students }\end{array}$ & 4.2 & 4.1 & 4.2 & 4.2 & Very Good \\
\hline 8. & $\begin{array}{l}\text { Observation sheet of lesson } \\
\text { plan implementation }\end{array}$ & 4.4 & 4 & 4.4 & 4.3 & Very Good \\
\hline \multicolumn{5}{|c|}{ Total } & 4.2 & Very Good \\
\hline
\end{tabular}

Before the product is tested the first revision I. Revision I is done on the basis of suggestions and input from expert lecturers, biology teachers, and peers.

Table 5. Results of questionnaire responses of students in the limited trial

\begin{tabular}{llll}
\hline Students & Handout & $\begin{array}{c}\text { Students } \\
\text { Worksheet }\end{array}$ & $\begin{array}{c}\text { Learning } \\
\text { Process }\end{array}$ \\
\hline $\mathbf{1}$ & 4.5 & 4 & 4.5 \\
$\mathbf{2}$ & 3.8 & 4.4 & 4.2 \\
$\mathbf{3}$ & 3.8 & 3.7 & 4 \\
$\mathbf{4}$ & 3.6 & 3.8 & 3.8 \\
$\mathbf{5}$ & 3.8 & 3.5 & 3.5 \\
$\mathbf{6}$ & 3.8 & 3.8 & 3.8 \\
$\mathbf{7}$ & 3.8 & 4.3 & 3.8 \\
$\mathbf{8}$ & 3.9 & 4.4 & 3.9 \\
$\mathbf{9}$ & 3.7 & 4 & 3.7 \\
$\mathbf{1 0}$ & 3.8 & 4.2 & 3.8 \\
$\mathbf{1 1}$ & 3.7 & 4.3 & 3.8 \\
$\mathbf{1 2}$ & 3.8 & 4.5 & 3.8 \\
\hline Average & 3.8 & 4.1 & 3.9 \\
\hline Category & Good & Very good & good \\
\hline
\end{tabular}

Limited trials were conducted on twelve grade $\mathrm{X} A$ students. The questionnaire scores from the trial results are shown in Table 5 . The results of the limited trials provide information that the students worksheet readability in terms of content, graphics, and language is easily understood by students. This is evident from the student's questionnaire assessment of each aspect of the components of the handout, student's worksheet, and learning process by obtaining an average score of 3.9 so that it falls into either category. Suggestions and input provided by the test subjects i.e. information obtained from limited trials is used to make revisions before more extensive trials are conducted.

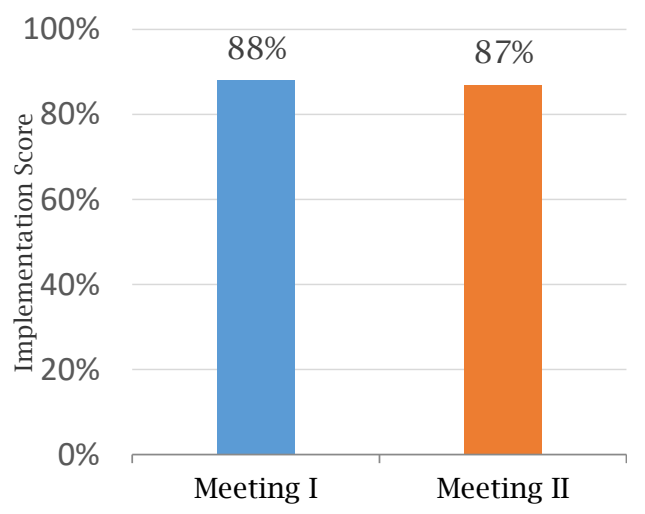

Figure 2.Diagram of percentage of lesson plan implementation

Revision II is based on the responses from students towards draft 2 at the limited trial stage. The implementation of extensive trials was carried out using draft III. The results of extensive trials in the form of the observation sheet scores lesson plan implementation, student 
questionnaire response scores to the device and the learning process, and scores of achievement outcomes of student's environmental care characters. The percentage of observations made by the lesson plan in the learning process is shown in Figure 2.

The percentage results obtained both at meetings I and II are greater than $80 \%$, therefore the lesson plan is practical. The results of student's responses to the handout, student's worksheet, and learning process are presented in Figure 3.

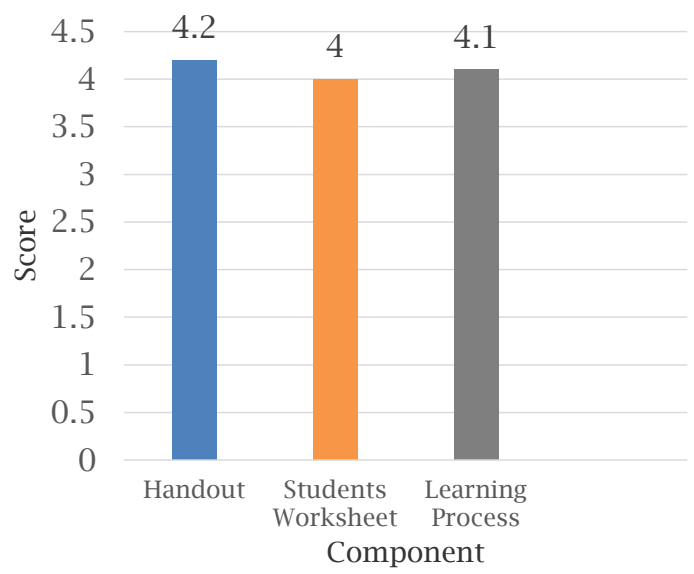

Figure 3.Average bar diagram of student response questionnaire scores in broad trials

Based on the analysis of Figure 3, the average response of students to the product and learning process is 4.1. A score of 4.1 based on Table 3 is included in the excellent category. Based on these results it can be concluded descriptively that the learning devices based on the STSE approach developed are practical. Seeing the student's response to the device and the learning process shows that students have a positive response to learning using the STSE approach.

The lowest acquisition score on the questionnaire of satisfaction with the handout so that it does not reach the maximum score is in the aspect of content eligibility that is about the suitability of the example with current conditions. The lowest acquisition score on the questionnaire satisfaction with student's worksheet so that it does not reach the maximum score is on the presentation aspect which is about clarity of instructions on the topic being discussed.

The lowest acquisition score on the questionnaire of satisfaction with the learning process so that it does not reach the maximum score is in the aspect of implementing the lesson plan that is about the learning resources used. The low score on these aspects of the assessment is a record of improvement so that the examples selected in the module are more in line with current conditions, the instructions for using the student's worksheet are clarified, and learning resources are more interesting and varied.

The results of completing the environmental care character questionnaire by students are presented in Figure 4.

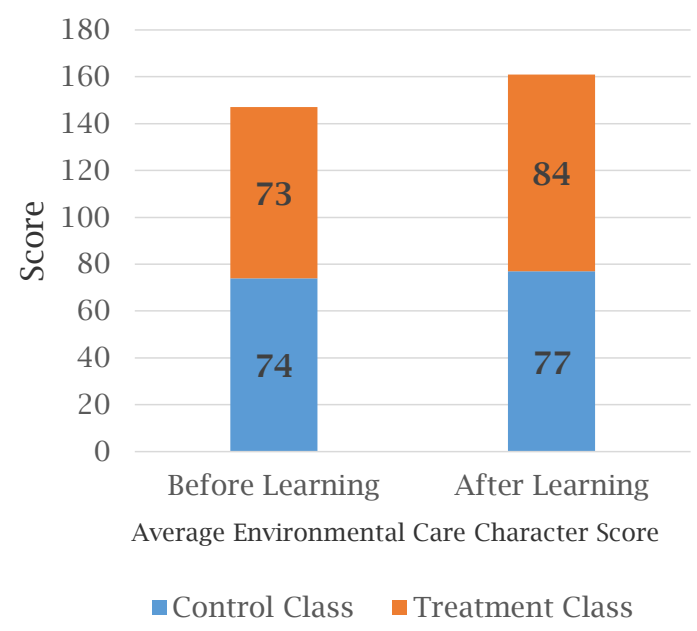

Figure 4.Mean bar charts of character scores before and after learning

Based on the analysis of Figure 4, the average acquisition score before learning is relatively the same, amounting to 74 in the control class and 73 in the experimental class. The acquisition of character scores after the learning process in the control class is 77 while in the experimental class is much greater at 84 .

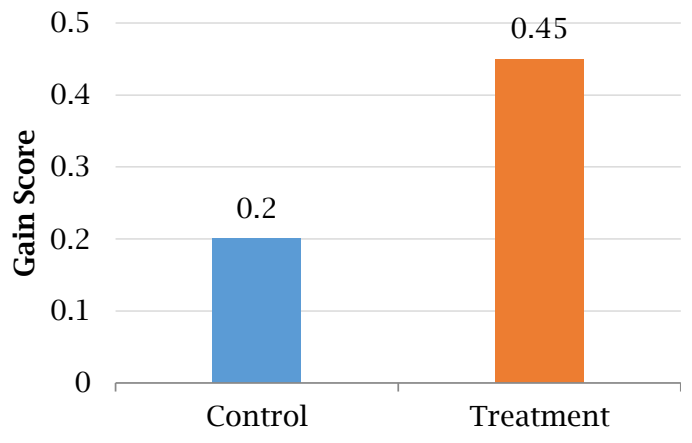

Figure 5.Diagram of the average gain character bar of environmental care 
The results of the environmental care character questionnaire before and after learning are then calculated the average gain score. Based on Table 3, the achievement gain score of the control class was 0.2 and included in the low category, while the experimental class was 0.45 and included in the category of "medium" so that the device developed can be said to be effective for improving the environmental care character of students. Achievement of student's score gain can be seen in Figure 5.

Figure 5 shows the achievement of the student's environmental care character values in the experimental class is higher than the control class. The assessment is based on a questionnaire score that represents the feelings students have before and after following the learning process using the STSE approach. Based on this acquisition, it can be concluded descriptively that the learning devices based on the STSE approach that were developed are effective in improving the student's environmental care character. This achievement proves that through the development of learning devices based on the STSE approach that presents the phenomena of environmental change and the various impacts that can be caused can stimulate student's feelings to be more concerned about the environment and strive to prevent and repair natural damage that has not happened or happened. This is consistent with what was conveyed by Gough who argues that children who are connected with their environment will have a social attitude and care for their environment.

In line with the results of Vijayabanu and Amarnath (2013) research which concluded that knowledge and attitudes about the environment have a positive influence on environmental care behavior, then environmental knowledge in the context of this research is elaborated through the STSE approach so that students have more control over the environment as a whole and ultimately grow a sense of caring for their environment.

Another relevant research that has been carried out is a study by Rosario (2008) which concluded that the STSE approach applied to environmental science subjects with activities originating from the local environment has proven to be effective in increasing environmental attitudes. Problems about the environment presented in STSE learning challenge student's willingness to do something in order to solve the problem. this is a basic theory as conveyed by Bandura (1977, $1981,1982)$ that behavioral change in learning is the result of beliefs or expectations about the results of the behavior and beliefs or expectations about one's ability to perform the behavior.

The successful implementation of the STSE approach to improve the character of caring for the environment cannot be separated from the development of a good STSE-based device and in accordance with its components and steps. This is in accordance with research conducted by Heni et al., (2015) who are trying to develop thematic learning devices with environmental-oriented STSE vision that have proven to be effective in achieving student activity and student understanding.

\section{Conclusion}

This study concludes that the product that has been developed is a STSE-based biology learning device otherwise feasible and effective to improve the student's environmental awareness character. The level of eligibility is evidenced by the acquisition of the average score of the results of the validation of expert lecturers, biology teachers, and peers in the aspects of content, graphics, and linguistic that is equal to 4.2 in the excellent category. The effectiveness of the product in improving the student's environmental care character is evidenced by the acquisition of the environmental care character questionnaire gain in the experimental class is greater than the control class. The gain of the experimental class score was 0.45 in the medium category, while the control class was 0.2 in the low category

\section{References}

Akcay, H., \& Yager, R. E. (2010). The impact of a science/technology/society teaching approach on student learning in five domains. Journal of Science Education and Technology, 19(6), 602-611. https://doi.org/ 10.1007/s10956-010-9226-7

Akker, J. van den, Bannan, B., Kelly, A. E., Nieveen, N., \& Plomp, T. (2007). An introduction to educational design 
research (T. Plomp \& N. Nieveen, Eds.). Retrieved from https://ris.utwente.nl/ws/portalfil es/portal/14472302/Introduction 20to_20education_20design_20res earch.pdf

Azwar, S. (1999). Metode penelitian. Yogyakarta: Pustaka Pelajar.

Gall, M. D., Gall, J. P., \& Borg, W. R. (2003). Educational research: An introduction (7th ed.). United States of America: Allyn and Bacon.

Hake, R. R. (1999). Analyzing change/gain scores. Retrieved from https://www.physics.indiana.edu/ sdi/AnalyzingChange-Gain.pdf

Heni, D. N., Binadja, A., \& Sulistyorini, S. (2015). Pengembangan perangkat pembelajaran tematik bervisi SETS berkarakter peduli lingkungan. Journal of Primary Education, 4(1), 30-35. Retrieved from https://journal.unnes.ac.id/sju/ind ex.php/jpe/article/view/6919

Jaya, I. M., Sadia, I. W., \& Arnyana, I. B. P. (2014). Pengembangan perangkat pembelajaran biologi bermuatan pendidikan karakter dengan setting guided inquiry untuk meningkatkan karakter dan hasil belajar siswa SMP. Jurnal Pendidikan IPA Ganesha, 4, 1-12. Retrieved from https://www.neliti. com/publications/122230/pengem bangan-perangkat-pembelajaranbiologi-bermuatan-pendidikankarakter-dengan

Kemendiknas. (2010). Pengembangan pendidikan budaya dan karakter bangsa. Retrieved from http://newindonesia.org/beranda/images/upl oad/dok/kurikulum/pengembanga n-pendidikan-budaya-dan-karakterbangsa.pdf

Kosim, M. (2011). Urgensi pendidikan karakter. KARSA: Journal of Social and Islamic Culture, IXI(1), 85-92. Retrieved from http://ejournal. stainpamekasan.ac.id/index.php/k arsa/article/view/78

Nieveen, N. (1999). Prototyping to reach product quality. In Design Approaches and Tools in Education and Training (pp. 125-135). https://doi.org/10.1007/978-94011-4255-7_10
Nurani, N. F., Ridlo, S., \& Susilowati, S. M. E. (2014). Pengembangan modul pendidikan lingkungan hidup (PLH) berbasis karakter untuk menumbuhkan wawasan dan karakter peduli lingkungan. Unnes Journal of Biology Education, 3(1), 53-60. Retrieved from https://journal.unnes.ac.id/sju/ind ex.php/ujbe/article/view/4155

Poedjiadi, A. (2010). Sains teknologi masyarakat metode pembelajaran kontekstual bermuatan nilai. Bandung: PT.Remaja Rosdakarya .

Purwanti, D. (2017). Pendidikan karakter peduli lingkungan dan implementasinya. DWIJA CENDEKIA: Jurnal Riset Pedagogik, 1(2), 14-20. https://doi.org/10. 20961/jdc.v1i2.17622

Putri, R. A. (2012). Pengembangan perangkat pembelajaran biologi terintegrasi karakter dan materi pendidikan lingkungan hidup (PLH). BioEdu, 1(3), 32-38. Retrieved from https://jurnalmahasiswa. unesa.ac.id/index.php/bioedu/arti cle/view/980

Rosario, B. I. Del. (2008). Science, Technology, Society and Environment (STSE) approach in environmental science for nonscience students in a local culture. DDC Professional Journal, 1(1). Retrieved from https://ejournals.ph/article.php?id $=700$

Salirawati, D. (2012). Percaya diri, keingintahuan, dan berjiwa wirausaha: tiga karakter penting bagi peserta didik. Jurnal Pendidikan Karakter, 2(2), 213-224. Retrieved from https://journal. uny.ac.id/index.php/jpka/article/v iew/1305

Sanjaya, W. (2008). Kurikulum dan pembelajaran (teori dan praktek pengembangan Kurikulum Tingkat Satuan Pendidikan). Retrieved from https://books.google.co.id/

Sanjaya, W. (2015). Perencanaan dan desain sistem pembelajaran. Retrieved from https://books.google.co.id/

Sugiyono. (2014). Metode penelitian pendidikan pendekatan kuantitatif, 
kualitatif dan $R \& D$. Bandung: Alfabeta.

Tanjung, C. A. (2020). Kayu raksasa di Taman Nasional Tesso Nilo Riau dijarah. Retrieved from News.Detik.Com.

Trianto. (2010). Mendesain perangkat pembelajaran inovatif-progresif: Konsep, landasan, dan implementasinya pada KTSP. Jakarta: Kencana Prenada Media Group.

Uar, N. D., Murti, S. H., \& Hadisusanto, S. (2016). Kerusakan lingkungan akibat aktivitas manusia pada ekosistem terumbu karang. Majalah Geografi Indonesia, 30(1), 88-95. https://doi.org/10.22146/ mgi.15626

Uno, H. B. (2011). Perencanaan pembelajaran. Jakarta: Bumi Aksara.

Vijayabanu, U., \& Amarnath, N. S. (2013). A study on environmental attitude and ecological behaviour. Indian
Journal of Health and Wellbeing, $4(4)$, 868-871. Retrieved from http://www.i-scholar.in/index.php /ijhw/article/view/92254\#

Yager, R. E., Choi, A., Yager, S. O., \& Akcay, H. (2009). A comparison of student learning in STS vs those in directed inquiry classes. Electronic Journal of Science Education , 13(2), 186208. Retrieved from https://ejse.southwestern.edu/arti cle/view/7805

Yuliani, K., \& Saragih, S. (2015). The development of learning devices based guided discovery model to improve understanding concept and critical thinking mathematically ability of students at islamic junior high school of Medan. Journal of Education and Practice, 6(24), 116-128. Retrieved from https://files.eric.ed.gov/ fulltext/EJ1078880.pdf 